\title{
Tattooing Vaccines Combining Biomedical Engineering for RNA Immunization
}

\author{
Wesley Luzetti Fotoran*, Nicole Kleiber and Gerhard Wunderlich \\ Department of Parasitology, Institute for Biomedical Sciences, University of São Paulo, Brazil
}

Submission: June 14, 2017; Published: June 27, 2017

"Corresponding author: Wesley Luzetti Fotoran, Department of Parasitology, Institute for Biomedical Sciences, University of São Paulo, Avenida Professor Lineu Prestes, 1374, 05508-000, Brazil, Email: wesleylfw@hotmail.com

\section{Changing the Traditional Muscle Approach to Focus on the Skin}

Producing recombinant antigens in GMP grade for vaccine purposes can be very difficult and in general, a time-consuming process [1]. Overcoming these two problems was one of the most important goals of DNA vaccines [2]. Producing and purifying plasmids that encode antigens has many advantages, namely easy storage and high stability [3]. However, there are different roadblocks concerning DNA for use in vaccines.

The main problems regarding DNA vaccines are

I. The capacity of inadvertedly integrating into the vaccine's genome and

II. Low immunogenicity [4].

In order to increase immunogenicity, a different methodology to deliver DNA vaccines was tried [5]. The most common way to deliver DNA vaccines involves muscle cells to generate immune responses [3].To increase immunogenicity and transfection efficiency the use of gene guns or transient electric pulses to amplify the DNA delivery to cells was proposed [6]. A new approach is currently focusing on the delivery of DNA vaccines to skin resident APC cells to elicit a better immune response. The delivery of DNA content is based on tattooing naked plasmid DNA or DNA complexed with polymers using coated micro needles [710]. This strategy focuses on monocytes that play a major role in adaptive immunity in the skin but also on professional APCs, leading to an increase inimmune responses. This configuration turns out to greatly improve the effectiveness of DNA vaccines. On another hand, despite the new strategies available, the plasmid DNA still has to be translocated to the nuclei of transfected cells. This drawback apparently can now be overcome with the advent of RNA-based approaches which present themselves as excellent alternatives to plasmid DNA vaccines $[11,12]$.

\section{RNA Vaccines}

RNA is the basis of biological life [13]. The RNA molecule is able to not only hold information, but also to be enzymatically active contrasting to DNA, which appears to function mainly as information storage. Next generation vaccines employ RNA to encode antigens against virus, parasites [14] and even cancer [3]. RNA possesses a number of advantages: RNA production is easily scaled up through in vitro production in high purity and is easily modified by molecular cloning. One very convenient aspect of RNA is that when delivered to the cytoplasm it may directly work as an effector molecule triggering antigen translation and therefore enhancing nucleic acid-based immunization. Different RNA vaccines are currently in use. The system deploys RNA, chemically modified or not, composed by a 5' defined sequence and a 3' end with a long poly (A) tail containing the gene of interest between these sequences [15]. This construction can be employed in other therapies besides vaccine formulations and has demonstrated effectiveness when administering lower amounts of RNA compared with DNA based approaches. A second construction implemented in RNA vaccines is biologically inspired by RNA viruses. It relies on a long, virus-derived protein-encoding (+) RNA molecule that possesses the ability of self-replicating the original RNA molecules (also termed "replicon") delivered to the cytoplasm [16]. This replication capacity provides waves of antigen production capable of being sustained for 48 hours with subsequent decrease triggered by Interferon gamma responses [17]. There are many RNA viruses potentially useful as RNA vaccines and it can be expected that this field in vaccine technology may grow exponentially in the near future. The replicon RNA can partially overcome the most crucial complications of RNA strategies, namely the instability of these molecules to environmental RNAses and the commonly short half-life of RNA molecules. 
Combining Biomedical Engineering with RNA Vaccines

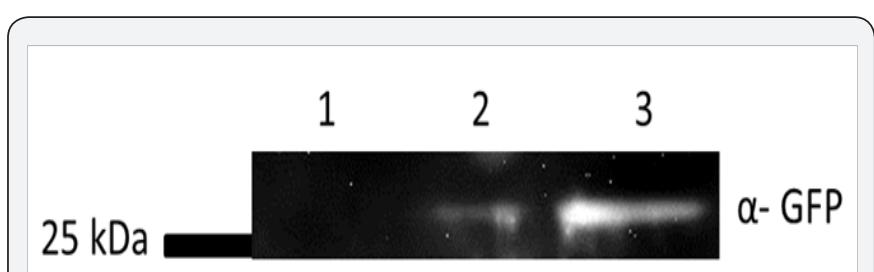

Figure 1: Western Blot from peritoneal macrophages. Animals wereimmunizedwith cationic liposomes with GFP replicon by intraperitonealroute. Macrophageswererecovered from the peritoneal region and submitted to Western blot against GFP expression.1-Control,Macrophages immunized with cationic liposomes not related to replicon; 2 and 3- Macrophages from animals immunized with cationic liposomes and GFP replicon (48h).

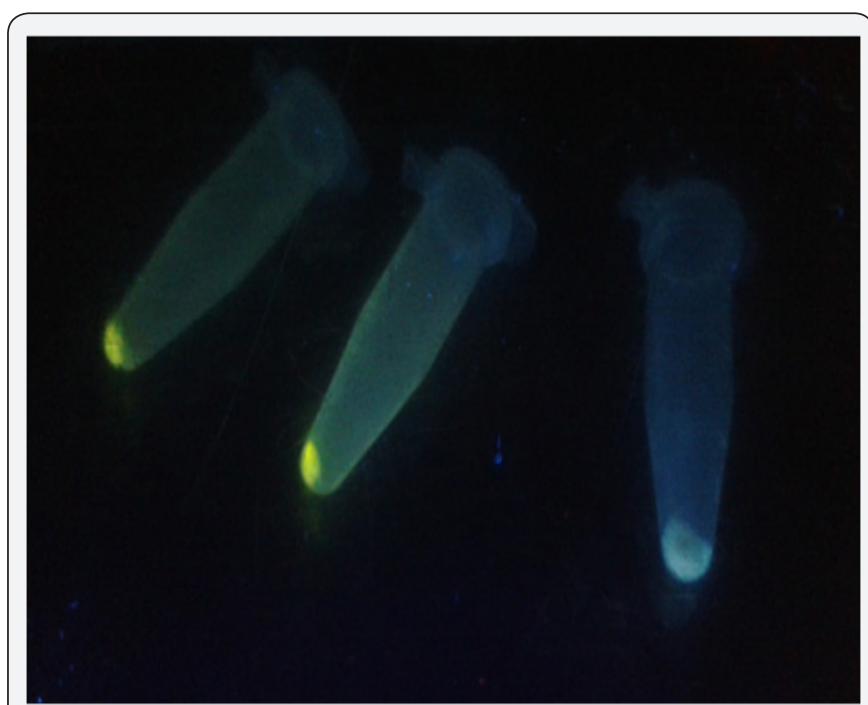

Figure 2: Comparison of transfected Vero cells. Respectively, two pelleted Vero cells transfected with cationic liposomes with GFP replicon showing GFP fluorescence under UV light (48h). In the right side, Vero cells transfected cationic liposomes with nanoLUC replicon (48h).

For many years, biomedical engineering was a technological approach to improve bioavailability of drugs and stabilize compounds with the benefit of decreasing the unwanted side effects of bioactive molecules [18]. For RNA vaccines, biomedical engineering might be a useful tool, especially considering liposome applications. Liposomes are bilamellar lipids structures that can provide a hydrophilic core for RNA loading, creating functional particles that protect RNA from degradation and increase their stability [19]. The composition of the lipids can be changed, allowing the creation of a cationic vesicle that functions as an effective transfecting particle. Finally, liposomes are naturally phagocytosed by monocytes, particularly macrophages that initialize adaptive immune responses [20]. Combining these features with a proper way of immunization might generate better effects than DNA immunization itself. DNA vaccines carried out by liposomes that focus the delivery to peritoneal macrophages can inducea strong humoral response against malarial antigens (in revision, our group). The use of
RNA replicons for producing GFP instead of pDNA encoding GFPis depicted on Figure 1. Peritoneal macrophages were used as a target and these strongly produce reporter protein, an effect not observed when transfecting DNA. Transfection of RNA complexes inside liposomes generated successful results in various strategies for RNA with [21] or without the replication features aforementioned [22]. Additionally, skin immunization achieves monocyte transfection by liposomes with potentially transfection of epithelial cells sustaining antigen production for natural drainage to lymph nodes, as shown in Figure 2. The combination of skin tattooing or immunization using microneedles with versatile RNA combined with nanoparticles, e.g. liposomes, can provide an exciting future for vaccines and other therapeutic approaches as biomarkers [23,24].

\section{Acknowledgment}

This work was founding by Fapesp , grant:2015/17174-7.

\section{References}

1. Rosano GL, Ceccarelli EA (2014) Recombinant protein expression in Escherichia coli: advances and challenges. Frontiers in Microbiology 5: 172 .

2. Ferraro B, Morrow MP, Hutnick NA, Shin TH, Lucke CE, et al. (2011) Clinical applications of DNA vaccines: current progress. Clinical Infectious Diseases: An Official Publication of the Infectious Diseases Society of America 53(3): 296-302.

3. Kutzler M A, Weiner DB (2008) DNA vaccines: ready for prime time? Nature Reviews. Genetics 9(10): 776-788.

4. Klinman DM, Takeno M, Ichino M, Gu M, Yamshchikov G, et al. (1997) DNA vaccines: safety and efficacy issues. Springer Seminars in Immunopathology 19(2): 245-256.

5. Dunachie SJ, Hill AV (2003) Prime-boost strategies for malaria vaccine development. The Journal of Experimental Biology 206(Pt 21): 37713779.

6. Wang S, Lu S (2013) DNA immunization. Current Protocols in Microbiology.

7. DeMuth PC, Min Y, Huang B, Kramer JA, Miller AD (2013) Polymer multilayer tattooing for enhanced DNA vaccination. Nature Materials 12(4): 367-376

8. Oosterhuis K, van den Berg JH, Schumacher TN, Haanen JB (2010) DNA Vaccines and Intradermal Vaccination by DNA Tattooing. In Current topics in microbiology and immunology 35: 221-250.

9. Van den Berg JH, Nujien B, Beijnen JH, Vincent A, van Tinteren H, et al. (2008) Optimization of intradermal vaccination by DNA tattooing in human skin. Human Gene Therapy 20(3): 181-189.

10. Zhang X, Yuan X, Shi H, Wu L, Qian H, et al. (2015) Exosomes in cancer: small particle, big player. Journal of Hematology \& Oncology 8(1): 83.

11. Leitner WW, Ying H, Restifo NP (1999) DNA and RNA-based vaccines: principles. progress and prospects. Vaccine 18(9-10): 765-777.

12. Schlake T, Thess A, Fotin-Mleczek M, Kallen KJ (2012) Developing mRNA-vaccine technologies. RNA Biology 9(11): 1319-1330.

13. Robertson MP, Joyce GF (2012) The origins of the RNA world. Cold Spring Harbor Perspectives in Biology 4(5).

14. Chahal JS, Khan OF, Cooper CL, McPartlan JS, Tsosie JK, et al. (2016) Dendrimer-RNA nanoparticles generate protective immunity against lethal Ebola, H1N1 influenza, and Toxoplasma gondii challenges with a single dose. Proc Natl Acad Sci U S A 113(29): E4133-E142. 
15. Pardi N, Hogan MJ, Pelc RS, Muramatsu H, Andersen H, et al. (2017) Zika virus protection by a single low-dose nucleoside-modified mRNA vaccination. Nature 543(7644): 248-251.

16. Beal J, Wagner TE, Kitada T (n.d.). Precision Design of Expression from RNA Replicons.

17. Beal J, Wagner TE, Kitada T, Azizgolshani O, Parker JM, et al. (2015) Model-Driven Engineering of Gene Expression from RNA Replicons. ACS Synthetic Biology 4(1): 48-56.

18. De Jong WH, Borm PJ (2008) Drug delivery and nanoparticles: applications and hazards. International Journal of Nanomedicine 3(2): 133-149.

19. Allen TM, Cullis PR (2013) Liposomal drug delivery systems: From concept to clinical applications. Advanced Drug Delivery Reviews 65(1): 36-48
20. Kelly C, Jefferies C, Cryan SA (2011) Targeted liposomal drug delivery to monocytes and macrophages. Journal of Drug Delivery.

21. Zimmer G (2010) RNA replicons-a new approach for influenza virus immunoprophylaxis. Viruses 2(2): 413-434.

22. Pardi N, Muramatsu H, Weissman D, Karikó K (2013) In Vitro Transcription of Long RNA Containing Modified Nucleosides. In Methods in molecular biology (Clifton, N.J.) 969: 29-42.

23. Kranz LM, Diken M, Haas H, Kreiter S, Loquai C, et al. (2016) Systemic RNA delivery to dendritic cells exploits antiviral defence for cancer immunotherapy. Nature 534(7607): 396-401.

24. Dunachie SJ, Hill AV (2003) Prime-boost strategies for malaria vaccine development. J Exp Biol 206(Pt 21): 3771-3779.

\section{Your next submission with Juniper Publishers will reach you the below assets}

- Quality Editorial service

- Swift Peer Review

- Reprints availability

- E-prints Service

- Manuscript Podcast for convenient understanding

- Global attainment for your research

- Manuscript accessibility in different formats

( Pdf, E-pub, Full Text, Audio)

- Unceasing customer service

Track the below URL for one-step submission https://juniperpublishers.com/online-submission.php 